\title{
Comparison of health problems related to work and environmental measurements in two office buildings with different ventilation systems
}

\author{
A S ROBERTSON, P S BURGE, A HEDGE, J SIMS, F S GILL, M FINNEGAN, \\ C A C PICKERING, G DALTON
}

\begin{abstract}
A cross sectional survey investigating "building sickness" was carried out in two buildings with similar populations of office workers but differing ventilation systems, one being fully air conditioned with humidification and the other naturally ventilated. The prevalence of symptoms related to work was assessed by a questionnaire administered by a doctor. A stratified, randomly selected sample of workers was seen ( $84 \%$ response).

Building sickness includes several distinct syndromes related to work, most of which were significantly more common in the air conditioned building than the naturally ventilated building-namely, rhinitis $(28 \% v$ $5 \%)$, nasal blockage and dry throat $(35 \% v 9 \%)$, lethargy $(36 \% v 13 \%)$, and headache $(31 \% v 15 \%)$. The prevalence of
\end{abstract}

Department of Thoracic Medicine, East Birmingham Hospital, Birmingham B9 5ST

A S ROBERTSON, MB, MRCP, Sheldon research fellow

P S BURGE, MD, FRCP, consultant physician (also a member of the Group for Occupational Lung Diseases)

Department of Applied Psychology, University of Aston, Birmingham

A HEDGE, PHD, ABPSs, lecturer in psychology

Institute of Occupational Health, University of Birmingham, Birmingham

I SIMS, MSC, research assistant

F S GILL, MSC, senior lecturer in occupational hygiene

Department of Thoracic Medicine, Wythenshawe Hospital, Manchester

M FINNEGAN, MB, MRCP, research registrar

C A C PICKERING, MRCP, MFOM, consultant thoracic physician (also a member of the Group for Occupational Lung Diseases)

Civil Service Medical Advisory Service

G DALTON, MB, MFOM, senior regional medical officer

Correspondence to: Dr Robertson. work related asthma and humidifier fever was low and did not differ significantly between the two buildings.

An environmental assessment of the offices was performed to attempt to identify possible factors responsible for the differences in the prevalence of disease. Globe temperature, dry bulb temperature, relative humidity, moisture content, air velocity, positive and negative ions, and carbon monoxide, ozone, and formaldehyde concentrations were all measured. None of these factors differed between the buildings, suggesting that building sickness is caused by other factors.

\section{Introduction}

The typical modern office building is a sealed structure ventilated by a mechanical heating, ventilation, and air conditioning system and lit primarily by fluorescent lamps. In such buildings ambient conditions are controlled so that they are within the range considered to give optimal comfort throughout the working day. Despite this widespread complaints of ill health in such offices have recently been documented. ${ }^{1-6}$ The pattern of symptoms reported usually includes headaches, lethargy and fatigue, sore eyes, and irritation of the upper respiratory tract and is commonly referred to as "building sickness" "; this has reportedly reached large proportions in some North American offices. The causal agent has so far not been found.

Turiel et al conducted an extensive study comparing an air conditioned office building in San Francisco where occupants reported health problems with a non-problematic building. ${ }^{\prime}$ Many different variables were measured, including 28 organic contaminants and odour, but none exceeded the recommended threshold limit. Carbon dioxide, fine particulates, hydrocarbons, and formaldehyde were, however, detected at higher concentrations indoors than outdoors. Indoor concentrations increased when the air conditioning system recirculated a greater proportion of the return air. Several questionnaire surveys of building sickness in the United Kingdom have shown the prevalence of complaints to be independent of smoking, ${ }^{458}$ to correlate with negative views on the adequacy of the ventilation 
and lighting systems, to be higher among women, and to be lower in naturally ventilated cellular offices ${ }^{4}$; but again causal factors have not been identified. Sterling and Sterling showed that complaints and symptoms of building sickness can be decreased by changing from sunlight simulating to standard cool white fluorescent lamps and by increasing the intake of fresh air from $25 \%$ to $87 \% .^{2}$ Subsequent complaints of eye irritation decreased by $31 \%$ and of headaches by $19 \%$. Either change alone produced only a $6-8 \%$ decrease in complaints, but the reasons for this remain unclear.

The symptoms of workers with building sickness are nonspecific. It is therefore important to differentiate between symptoms that are related to work and those that are not, and to compare the prevalence of symptoms with that in control populations. Such measurements have yet to be performed. This study aimed to rectify these limitations by investigating the prevalences of health problems related to work in two office buildings, one air conditioned and the other naturally ventilated, and to correlate these with environmental measurements.

\section{Subjects and methods}

A cross sectional study was conducted on office workers performing similar clerical and managerial tasks in two adjacent office buildings. One building was heated by radiators with open window ventilation, the other was fully air conditioned with sealed windows. The air conditioner included preheaters and humidification by water spray followed by chiller and heater baffles. Unlike other buildings that have been studied there was no recirculation of return air. A total of 288 workers were randomly selected from rooms in both buildings after initial stratification of the rooms according to floor level and aspect (north east, north west, south east, south west) so that a representative sample was obtained.

A questionnaire administered by an interviewer was given to each worker without the interviewer having knowledge of which building the worker worked in. Interviewing took place in a hall that was communal to workers from both buildings and sited adjacent to a corridor connecting the buildings. Workers were called from both buildings simultaneously. Each worker completed a numbered sheet with details of name, office, building, etc, and handed this to a clerk before the interview; the sheet was matched with the questionnaire only after the interview. No such details were requested during the interview, which was therefore performed blind. The questions were designed to cover a wide range of symptoms and symptom complexes, both specific and non-specific, that may be related to different characteristics of the office environment. ${ }^{6}$ The questionnaire also investigated the relation between these symptoms and work (date of onset and whether they improved on rest days).

Questions were classified into general groups, each characterised by a possible environmental mechanism, which was then investigated further. (1) Symptoms originally thought to be caused by low humidity: (a) dry throat or stuffy nose, or both; (b) dry skin; (c) difficulty with wearing contact lenses. (2) Symptoms of possible "allergic" reaction in nose and eyes: $(a)$ itching and irritation or watering of the eyes; (b) itchy or runny nose. (3) Symptoms of possible humidifier fever: $(a)$ fever; (b) lassitude; $(c)$ joint aches and pains; $(d)$ muscle pains; $(e)$ headache. Humidifier fever was diagnosed when at least four of these symptoms were present, occurred repeatedly, and lasted one to two days, particularly on the first day of work after a break. (4) Symptoms suggestive of asthma: (a) chest tightness; (b) wheeze; (c) breathlessness. (5) Symptoms whose cause was unclear: (a) lethargy or tiredness; $(b)$ headache.

Symptoms were regarded as related to work if they improved away from work and had started for the first time, or become more severe, after the subject had started to work in the building in question. Results are given only for symptoms related to work.

After the initial study of the prevalence of symptoms we carried out a survey of occupational hygiene in the buildings to identify environmental factors that might have caused the symptoms. The survey was performed over three separate weeks in January, April, and June, as we thought that external environmental conditions might be important.

Seven rooms that were each occupied by several workers in the airconditioned building and three such rooms in the naturally ventilated building were selectively sampled for further study. Five of the air conditioned rooms and the three naturally ventilated rooms were selected from the initial survey because of a high prevalence of symp- toms among the workers. The remaining two rooms in the air conditioned building had a low prevalence of symptoms.

Hygiene measurements were taken in all the sampled rooms. Globe temperature (using a $150 \mathrm{~mm}$ diameter globe thermometer was measured at head height for a seated person. A whirling hygrometer was used to find wet and dry bulb temperatures, and with these readings relative humidity and moisture content were calculated from a psychrometric chart. Air velocity was calculated using Bedford's equation ${ }^{9}$ with readings from a katathermometer. Positive and negative ions were measured using a Medion air ion analyser equilibrated for 20 minutes. Concentrations of the pollutants carbon monoxide, ozone, and formaldehyde were measured. Carbon monoxide was measured for 30 seconds at desk level using a carbon monoxide indicator (Dupont CO 2000). Ozone was detected by passing office air sampled at a rate of 3 litres/min through a solution of ethylene oxide. The resulting reaction emitted light, which was measured by a photomultiplier (Analytical Instrument Co model 560 portable ozone monitor) in parts per million. Similarly, formaldehyde was assayed by passing air through a sodium bisulphite solution, ${ }^{10}$ which was analysed with a Pye SP 30 spectrophotometer set at $580 \mathrm{~nm} .{ }^{11}$ The analysis could detect concentrations as low as $0.025 \mathrm{ppm}$.

\section{Results}

The questionnaire was completed by 241 workers (an $84 \%$ response), $129(89 \%)$ from the air conditioned building and $112(78 \%)$ from the naturally ventilated building. Table I compares the prevalences of the various symptoms in the two buildings. There were considerable differences between the two groups, particularly in the number of workers with "dry" symptoms and nasal and eye symptoms suggesting allergy. Symptoms of lethargy and headache related to work were also common, affecting about a third of the workers in the air conditioned building and $14 \%$ of those in the naturally ventilated building. There was a higher percentage of workers with symptoms suggestive of work related asthma in the air conditioned building, although the difference did not achieve significance. Humidifier fever was uncommon, with only two workers, both from the air conditioned building, thought probably to have the condition.

TABLE I-Prevalence of symptoms related to work in naturally ventilated building compared with air conditioned building. (Figures are numbers $(\%)$ of subjects)

\begin{tabular}{|c|c|c|c|}
\hline \multirow[b]{2}{*}{ Symptoms } & \multicolumn{2}{|c|}{ Ventilation system } & \multirow[b]{2}{*}{ p Value } \\
\hline & $\begin{array}{c}\text { Natural } \\
(n=112)\end{array}$ & $\begin{array}{c}\text { Air conditioned } \\
(n=129)\end{array}$ & \\
\hline $\begin{array}{l}\text { "Dry" symptoms: } \\
\text { Stuffy nose or dry throat, or both } \\
\text { Dry skin } \\
\text { Difficulty wearing contact lenses }\end{array}$ & $\begin{array}{c}10(9) \\
1 / 7(14)\end{array}$ & $\begin{array}{l}45(35) \\
7(5) \\
4 / 9(44)\end{array}$ & $\begin{array}{l}<0.001 \\
<0.05 \\
\text { NS }\end{array}$ \\
\hline $\begin{array}{l}\text { Symptoms suggestive of allergic reaction: } \\
\text { Blocked, runny or itchy nose } \\
\text { Watering or itching of eyes }\end{array}$ & $\begin{array}{l}6(5) \\
8(7)\end{array}$ & $\begin{array}{l}35(27) \\
28(22)\end{array}$ & $\begin{array}{l}<0.001 \\
<0.01\end{array}$ \\
\hline $\begin{array}{l}\text { Symptoms suggestive of asthma: } \\
\text { Chest tightness } \\
\text { Wheeze } \\
\text { Shortness of breath }\end{array}$ & $\begin{array}{l}4(4) \\
5(5) \\
2(2)\end{array}$ & $\begin{array}{r}9(7) \\
11(9) \\
4(3)\end{array}$ & $\begin{array}{l}\text { NS } \\
\text { NS } \\
\text { NS }\end{array}$ \\
\hline $\begin{array}{l}\text { Symptoms with uncertain cause: } \\
\text { Lethargy } \\
\text { Headache }\end{array}$ & $\begin{array}{l}15(13) \\
17(15)\end{array}$ & $\begin{array}{l}47(36) \\
40(31)\end{array}$ & $\begin{array}{l}<0.001 \\
<0.01\end{array}$ \\
\hline
\end{tabular}

The hygiene surveys were performed during one week in January, April, and June when the mean external temperatures during working hours were $7.1^{\circ} \mathrm{C}, 8.2^{\circ} \mathrm{C}$, and $12.2^{\circ} \mathrm{C}$ respectively. There were no significant differences in any of the environmental variables measured between the two buildings (table II). The conditions were mostly within the ranges recommended for office buildings. ${ }^{12}$ Relative humidity occasionally fell below $40 \%$, mainly in January, when external temperatures were lower, but there was no significant difference in the frequency with which this occurred between the two buildings. Air velocity was generally lower than is thought comfortable, ${ }^{912}$ although again there were no significant differences between the buildings. Ozone readings ranged from 0.0 to 1.6 parts per billion (recommended maximum indoor concentration 50 parts per billion) and carbon monoxide concentrations from one to seven parts per million (threshold limit 50 parts per million). All the formaldehyde readings were below 0.025 parts per million. 
TABLE II-Environmental measurements made in fanuary, April, and fune in naturally ventilated and air conditioned buildings (mean external temperatures $7 \cdot 1^{\circ} \mathrm{C}$, $8 \cdot 2^{\circ} \mathrm{C}$, and $12 \cdot 2^{\circ} \mathrm{C}$ respectively)

\begin{tabular}{|c|c|c|c|c|c|c|c|c|}
\hline Building & $\begin{array}{l}\text { No of } \\
\text { readings }\end{array}$ & $\begin{array}{c}\text { Globe } \\
\text { temperature }\left({ }^{\circ} \mathrm{C}\right)\end{array}$ & $\begin{array}{c}\text { Dry bulb } \\
\text { temperature }\left({ }^{\circ} \mathrm{C}\right)\end{array}$ & $\begin{array}{c}\text { Relative } \\
\text { humidity }(\%)\end{array}$ & $\begin{array}{c}\text { Moisture } \\
\text { content }(\mathrm{kg} / \mathrm{kg})\end{array}$ & $\underset{\text { velocity }(\mathrm{m} / \mathrm{s})}{\mathrm{Air}}$ & $\begin{array}{c}\text { Positive } \\
\text { ions (ions } / \mathrm{cm}^{3} \text { ) }\end{array}$ & $\begin{array}{c}\text { Negative ions } \\
\left.\text { (ions } / \mathrm{cm}^{3}\right)\end{array}$ \\
\hline \multicolumn{9}{|c|}{ fanuary } \\
\hline $\begin{array}{l}\text { Naturally ventilated: } \\
\text { Mean (SD) } \\
\text { Range }\end{array}$ & 18 & $\begin{array}{l}24 \cdot 2(3 \cdot 1) \\
22 \cdot 5 \cdot 35 \cdot 0\end{array}$ & $\begin{array}{l}22.8(0.86) \\
21.5-25 \cdot 0\end{array}$ & $\begin{array}{l}44 \cdot 7(5 \cdot 7) \\
33 \cdot 0-48 \cdot 0\end{array}$ & $\begin{array}{l}0.00786(0.00077) \\
0.0064-0.0094\end{array}$ & $\begin{array}{l}0.052(0.05) \\
0.00-0.16\end{array}$ & $\begin{array}{l}185^{*}(13 \cdot 2) \\
175-200\end{array}$ & $\begin{array}{l}177 *(25 \cdot 2) \\
150-200\end{array}$ \\
\hline $\begin{array}{l}\text { Air conditioned: } \\
\text { Mean }(\mathrm{SD}) \\
\text { Range }\end{array}$ & 45 & $\begin{array}{l}22 \cdot 7(1 \cdot 29) \\
20 \cdot 5-27 \cdot 0\end{array}$ & $\begin{array}{l}22 \cdot 8(1 \cdot 20) \\
20 \cdot 5-25 \cdot 0\end{array}$ & $\begin{array}{l}43 \cdot 2(6 \cdot 1) \\
30 \cdot 0-58 \cdot 0\end{array}$ & $\begin{array}{l}0.00748(0.00073) \\
0.0058-0.0088\end{array}$ & $\begin{array}{l}0.069(0.04) \\
0.00-0.21\end{array}$ & $\begin{array}{l}342+(123) \\
175-500\end{array}$ & $\begin{array}{l}256 \dagger(104) \\
150-350\end{array}$ \\
\hline $\begin{array}{l}\text { Naturally ventilated: } \\
\text { Mean (SD) } \\
\text { Range }\end{array}$ & 12 & $\begin{array}{l}22 \cdot 5(1 \cdot 3) \\
20 \cdot 0-23 \cdot 5\end{array}$ & $\begin{array}{l}21 \cdot 8(1 \cdot 4) \\
19 \cdot 0-23 \cdot 0\end{array}$ & $\begin{array}{c}\text { April } \\
42 \cdot 3(1 \cdot 8) \\
39 \cdot 0-44 \cdot 0\end{array}$ & $\begin{array}{l}0.00628(0.00056) \\
0.0056-0.0072\end{array}$ & $\begin{array}{l}0.053(0.04) \\
0.00-0.13\end{array}$ & & \\
\hline $\begin{array}{l}\text { Air conditioned: } \\
\text { Mean (SD) } \\
\text { Range }\end{array}$ & 30 & $\begin{array}{l}23 \cdot 0(1 \cdot 47) \\
20 \cdot 0-26 \cdot 0\end{array}$ & $\begin{array}{l}22 \cdot 7(1 \cdot 35) \\
20 \cdot 0-25 \cdot 0\end{array}$ & $\begin{array}{l}43 \cdot 5(2 \cdot 6) \\
38 \cdot 0-50 \cdot 0\end{array}$ & $\begin{array}{l}0.00747(0.00053) \\
0.0066-0.0084\end{array}$ & $\begin{array}{l}0.062(0.032) \\
0.00-0.18\end{array}$ & & \\
\hline $\begin{array}{l}\text { Naturally ventilated: } \\
\text { Mean (SD) } \\
\text { Range }\end{array}$ & 20 & $\begin{array}{l}23 \cdot 6(1 \cdot 02) \\
21 \cdot 5-25 \cdot 5\end{array}$ & $\begin{array}{l}22 \cdot 9(1 \cdot 1) \\
21 \cdot 3-24 \cdot 1\end{array}$ & $\begin{array}{c}\mathcal{f} u n e \\
46 \cdot 8(4 \cdot 3) \\
42 \cdot 0-53 \cdot 0\end{array}$ & $\begin{array}{l}0.00748(0.00089) \\
0.0058-0.0084\end{array}$ & $\begin{array}{l}0.093(0.010) \\
0.036-0.270\end{array}$ & & \\
\hline $\begin{array}{l}\text { Air conditioned: } \\
\text { Mean }(\mathrm{SD}) \\
\text { Range }\end{array}$ & 22 & $\begin{array}{l}22 \cdot 9(1 \cdot 02) \\
21 \cdot 0-24 \cdot 0\end{array}$ & $\begin{array}{l}22 \cdot 9(1 \cdot 0) \\
20 \cdot 8-24 \cdot 0\end{array}$ & $\begin{array}{l}49 \cdot 9(5 \cdot 9) \\
38 \cdot 0-58 \cdot 0\end{array}$ & $\begin{array}{l}0.00877(0.00077) \\
0.0074-0.0098\end{array}$ & $\begin{array}{l}0.070(0.004) \\
0.008-0.170\end{array}$ & & \\
\hline
\end{tabular}

\section{Discussion}

In this study randomly selected groups of similar office workers were interviewed with the interviewer blind as to which office the worker worked in. Over $80 \%$ of the sampled workers were seen. The significant excess of symptoms found in the workers in the air conditioned building compared with those in the naturally ventilated building can therefore confidently be attributed to the building in which they worked.

Humidifier fever is the best recognised non-infective disease related to air conditioning systems and occurs mainly in industrial buildings, particularly in printing works. ${ }^{13}$ The disease often results from exposure to humidifiers that are contaminated with a wide range of micro-organisms. ${ }^{14}$ None of the workers in this study had unequivocal humidifier fever, although two workers with probable humidifier fever were identified in the air conditioned building. The lack of humidifier fever in our study probably relates to the cleanliness of the humidifiers, which was due to the lack of recirculated air passing through them and perhaps also to the use of biocides.

Asthma from exposure to contaminated humidifiers was first recognised by Solomon in $1974^{15}$ and was more recently identified in a printing works. ${ }^{14}$ Cleaning of the humidifier without any other change in work practice resulted in a substantial improvement in the affected workers, showing that the humidifier was the source of the asthma. A study of nine buildings with different types of ventilation showed that symptoms suggestive of asthma were related to air conditioned buildings with humidification rather than without humidification, again suggesting that the humidifier was the source of the symptoms. ${ }^{6}$ In our study symptoms suggestive of occupational asthma were uncommon; although they were twice as prevalent in the air conditioned building, the difference was not significant. There was probably a low prevalence of genuine occupational asthma in the air conditioned building.

Watering and irritation of the nose and eyes, clinically similar to that seen in allergic reactions, were largely confined to the air conditioned building. Previous work has shown that these symptoms are related to sealed buildings whether or not humidifiers have been installed, raising some doubt about whether they are due to allergy to the humidifier organisms or to other factors related to air conditioning systems. ${ }^{6}$

Dry throat, a stuffy nose, dry eyes, and dry skin have in the past been attributed to working in an atmosphere with low relative humidity or moisture content. Our study clearly showed an excess of these symptoms in the air conditioned building. The hygiene study, however, showed that the relative humidity tended to remain within the suggested range for comfort of $40-50 \%$. More readings below $40 \%$ occurred in the air conditioned building than in the naturally ventilated building during the week in January, but the excess was not significant. All readings of moisture content exceeded the recommended minimum of $0.0055 \mathrm{~kg} / \mathrm{kg}$. Although previous work has shown symptoms of dryness to be particularly related to buildings with a humidifier and therefore to material derived from the humidifier rather than the lack of humidity, the symptoms are also more prevalent in sealed buildings without humidifiers than in naturally ventilated buildings, ${ }^{6}$ which raises considerable doubt about their aetiology.

Work related lethargy or headache, or both, has been recognised only recently as a problem in sealed buildings and is the symptom complex colloquially called "building sickness.", 45 The prevalence of these symptoms in our study was similar to that found in other sealed buildings ${ }^{6}$ : they occurred in $15 \%$ of those working in the naturally ventilated building and $30 \%$ of those in the air conditioned building. The significant excess in the air conditioned building was probably not caused by the humidifier itself as the symptoms were also present in the naturally ventilated building. This is borne out by a prevalence of lethargy related to work of $45 \%$ found previously in a mechanically ventilated building without humidification. ${ }^{6}$ Many causes have been suggested for these symptoms.

No single environmental variable tested explained the difference in the prevalence of symptoms. The temperature remained within the World Health Organisation's recommended range of $18-24^{\circ} \mathrm{C}$. Mean values were similar to Fanger's predicted temperature for optimal thermal comfort of $22 \cdot 6^{\circ} \mathrm{C},{ }^{16}$ and although small variations from this can produce many complaints there were no significant differences in temperature between the two buildings. Air velocity was generally below the $0.075 \mathrm{~m} / \mathrm{s}$ recommended to prevent a sense of stagnant atmosphere ${ }^{9}$ but did not differ between the two buildings.

A build up of indoor pollutants has been suggested as a possible cause of many of the symptoms of building sickness. Similar symptoms have been reported in "tight" homes insulated with ureaformaldehyde. ${ }^{17}$ Our study showed undetectable formaldehyde concentrations in both buildings, making it improbable that formaldehyde was a cause. Ozone and carbon monoxide could also cause many of the symptoms, but ozone readings were lower in the offices than outdoors and carbon monoxide was well within acceptable limits. Whether a certain concentration of ozone is required for a feeling of "freshness" is unknown. Lack of negative ions has also been suggested as a cause of non-specific symptoms in air conditioned buildings. ${ }^{18}$ The buildings in our study had ion concentrations below those thought to be optimal, but the concentrations were similar in both buildings, making it improbable that they were the sole cause of the symptoms. They may possibly contribute to the symptoms in naturally ventilated buildings, although Hedge and 
Eleftherakis showed no improvement in performance tests when the concentrations of negative ions vjere increased. ${ }^{19}$ Other possible causes for the symptoms have been suggested, including the spectral quality of light from fluorescent lamps and photochemical smog catalysed by fluorescent lighting systems. ${ }^{2}$

The possibility that group suggestion may explain the increased prevalence of symptoms in the sealed building must be considered. Such suggestion could come from other workers or from the media in view of the current concern about these problems. This could give rise either to a "mass hysteria" effect or simply to heightened awareness in one particular group of people. Symptoms due to mass hysteria are usually vague, often neurological, and often associated with nausea, dizziness, and fainting. Hyperventilation may occur with these symptoms, which are mostly transient and resolve rapidly. ${ }^{20}$ None of these features were present in the workers that we saw.

The possibility of increased awareness in one particular group was minimised in our study by the management and unions from both buildings participating simultaneously throughout. The reason for the "medical survey" was not explained to the office workers. The prevalences of the various symptoms related to work have been found to differ consistently with different ventilating systems. ${ }^{6}$ Similarly, the prevalences of symptoms have been found to decrease after a change in ventilation and lighting systems. ${ }^{2}$ Both of these facts suggest that the cause is physical rather than psychological.

In conclusion, we believe that most of the respiratory, eye, and nasal symptoms in air conditioned buildings are related to the ventilation system. On current evidence lethargy and headache are probably related to factors other than the ventilation system. Factors that need investigating include the stability of the environment in sealed buildings, the effects of different types of work practice, and the removal of control of lighting and ventilation from the individual worker, as well as more extensive study of the quality of indoor atmosphere.

\section{References}

1 Turiel I, Hollowell CD, Miksch RR, Rudy JV, Young RA. The effects of reduced ventilation on indoor air quality in an office building. Atmospheric Environment

2 Sterling E, Sterling T. The impact of different ventilation levels and fluorescent lighting types on building illness: an experimental study. Can $\mathcal{F}$ Public Health

Sterling E, Sterling T, McIntyre D. New health hazards in sealed buildings. American Institute of Architects fournal 1983 April:64-7.

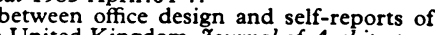
Kingdom. Fournal of Architecture and Planning Research $1984 ; 3: 163-74$

5 Hedge A. Ill-health amongst office workers: an examination of the relationship between office design and employee well-being. In: Grandjean E, ed. Ergonomics and health in modern offices. London: Taylor and Francis, 1984:46-51.

6 Finnegan MJ, Pickering CAC, Burge PS. Sick building syndrome: prevalence studies. Br Med F 1984;289:1573-5.

7 Sterling TD, Sterling E, Dimich-Ward H. Building illness in the white-collar workplace. International fournal of Health Services 1983;13:277-87.

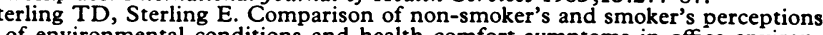
of environmental conditions and health comfort symptoms in office environments with and without smoking. In: Grandjean E, ed. Ergor

9 Chrenko FA, ed. Bedford's basic principles of ventilation and heating. 3rd ed. London: Lewis, 1974:26-7.

10 Gill FS, Ashton I. Monitoring for health hazards at work. London: Grant McIntyre Ltd, 1982:43-5.

11 National Institute for Occupational Safety and Health. Manual of analytical methods. 2nd ed. Vol 1. Ohio: National Institute for Occupational Safety and

12 McIntyre DA. Indoor climate. Barking, England: Applied Science Publishers Ltd,

13 Pickering CAC. Humidifier fever. Eur $\mathcal{F}$ Respir Dis 1982;63 (suppl 123):104-7S. 4 Burge PS, Finnegan MJ, Horsfield N, et al. Occupational asthma in a factory with a contaminated humidifier. Thorax $1985 ; 40: 248-54$.

15 Solomon WR. Fungus aerosols arising from cold-mist vaporizers. $f$ Allergy Clin Immunol $1974 ; 54: 222-8$.

16 Fanger PO. Thermal comfort. New York: McGraw Hill, 1972:19-64.

7 Breysse PA. The health cost of tight homes. $\mathcal{F} A M A$ 1981;245:267-8.

Hawkins $L H$. The influence of air ions, temperature and humidity on subjective wellbeing and comfort. Fournal of Environmental Psychology 1981;1:279-92. psye A, Eleftherakis E. Air ionization: an evaluation of its physiological and

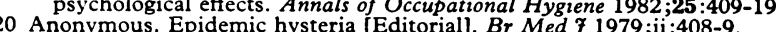

\title{
Nocturnal hypoglycaemia in patients receiving conventional treatment with insulin
}

\author{
S PRAMMING, B THORSTEINSSON, I BENDTSON, B RØNN, C BINDER
}

\begin{abstract}
The prevalence of nocturnal biochemical hypoglycaemia -that is, blood glucose concentrations below $3 \mathrm{mmol} / 1$ $(55 \mathrm{mg} / 100 \mathrm{ml}$ ) - was evaluated in a random sample of 58 insulin dependent diabetics receiving twice daily insulin. Seventeen patients had at least one blood glucose value below $3 \mathrm{mmol} / 1(55 \mathrm{mg} / 100 \mathrm{ml})$ and five a value below $2 \mathrm{mmol} / 1(36 \mathrm{mg} / 100 \mathrm{ml})$ during the night. Both bedtime (2300) and fasting morning (0700) blood glucose concentrations were significantly lower in the group
\end{abstract}

Steno Memorial Hospital, DK-2820 Gentofte, Denmark

$S$ PRAMMING, MD, research fellow

B THORSTEINSSON, MD, research fellow

B RØNN, MD

C BINDER, MD, chief physician

University Hospital, Hvidovre, Denmark

I BENDTSON

Correspondence to: Dr Pramming. with nocturnal hypoglycaemia compared with the group without $(p<0.00001)$. If the bedtime blood glucose concentration was below $6 \mathrm{mmol} / 1(108 \mathrm{mg} / 100 \mathrm{ml})$ the risk of nocturnal hypoglycaemia was $80 \%$ (95\% confidence limits 51-96\%). If the bedtime blood glucose concentration was above $6 \mathrm{mmol} / 1$ the likelihood of hypoglycaemia not occurring during the night was $88 \%$ (74-96\%).

The mean glycosylated haemoglobin $A_{1 c}\left(H_{b} A_{1 c}\right)$ concentration in the group with nocturnal biochemical hypoglycaemia $(8 \cdot 2$ (range $5 \cdot 0-12 \cdot 4) \%$ ) was significantly lower than that in the group without $(9 \cdot 4(7 \cdot 0-14 \cdot 2) \%)$ $(\mathbf{p}<0.02)$. The prevalence of nocturnal hypoglycaemia in the patients receiving twice daily insulin $(29 \%)$ was compared with that in 15 patients receiving thrice daily insulin $(47 \%)$ and was not found to be significantly different. The likelihood of this risk being greater with thrice daily insulin was, however, $88 \%$. No patient with nocturnal biochemical hypoglycaemia woke up during the night with symptomatic hypoglycaemia.

Nocturnal biochemical hypoglycaemia is common during twice daily treatment with insulin, and low values of $\mathrm{HbA}_{1 \mathrm{C}}$ might be associated with a higher risk of such hypoglycaemia. The blood glucose concentration at 